\title{
DEVELOPING CRITICAL READING COMPETENCES AT THE ENGLISH LESSONS: TEACHING TEXT-MESSAGE WRITING
}

\author{
Nadejda MIŞENINA, teacher \\ PI Theoretical Lyceum „Mihai Eminescu”, mun. Balti \\ ORCID iD: 0000-0002-1175-3281
}

\begin{abstract}
The quality of our life and that of what we produce, make, or build depend precisely on the quality of our thought. Therefore excellence in thought must be systematically cultivated. Critical thinking is defined as the process of determining the authenticity, accuracy, and worth of information or knowledge claims. Being able to determine the main idea helps readers to recall important information. Locating the main idea and significant details helps the reader understand the points the writer is attempting to express. Identifying the relationship between these will improve comprehension.
\end{abstract}

Keywords: critical thinking, critical reading, graded instruction, stated main idea, implied main idea, text-message, valid inference, key details, comprehension.

\section{DEZVOLTAREA COMPETENȚELOR DE LECTURĂ CRITICĂ LA LECȚIILE DE LIMBA ENGLEZĂ: SCRIEREA UNUI MESAJ-TEXT}

Rezumat. Articolul dat reflectă aspecte de dezvoltare a abilităţilor de gândire critică în procesul lecturii la orele de limba engleză. Obiectivul propus este de a demonstra necesitatea implicării elevilor in activități de lectură critică, mecanism esențial în dezvoltarea capacităților de reflecție analitică, a decodării corecte a c, a face inferențe valide în baza materialului factologic. Strategia descrisă se propune profesorilor de limba străină, ca utilizând-o, să formeze discipolilor abilități ce le vor îmbunătăţi calitatea studiilor.

Cuvinte-cheie: gândire critică, lectură critică, instruire graduală, idee explicită, idee dedusă, mesajul textului, inferenţă validă, detalii esenţiale, comprehensiune.

According to Barry K. Beyer „Critical thinking skills figure prominently among the goals for education, whether one asks developers of curricula, educational researchers, parents, or employers. Although there are some quite diverse definitions of critical thinking nearly all emphasize the ability and tendency to gather, evaluate, and use information effectively" [1].

Developing students' competence in critical thinking is an imperative requirement of the National Curricula for Foreign Languages, 2010 and 2019 [3; 4]. The Guide to Implementation of the National Curriculum for Foreign Languages 2010 emphasizes that in order to manage information taken from different sources, students must be able to apply thinking procedures, use data efficiently and make critical analysis. It also states that it is necessary to develop students' ability to think independently, make correct decisions in different situations and solve certain problems [9]. The reading of textbooks plays an important role in the content fields; thus, teaching critical reading should be at the core of any discussion of critical thinking. The ability to identify the main idea in a text, whether it is stated directly or inferred, is pivotal for students to gain meaning when reading.

The aim of this article is to draw foreign language teachers' attention to the necessity of timely and systematic development of students' critical reading competence in determining a text message and to offer a strategy used by me at the lessons of English for helping students master this fundamental skill and read with better understanding of the material.

Since 2014-2015 academic year the assignment of identifying the text message has been included in the Baccalaureate Examination in English, challenging students to develop this important skill and demanding from teachers of English that an effective methodology of teaching it should be elaborated and systematically applied.

Moreover, international language examinations, based on the Common European Framework of Reference for Languages, such as: FCE, TOEFL, 
IELTS, etc., which have recently grown in popularity among school undergraduates, also test students' ability to recognize the main point being made in a paragraph or text and emphasize the necessity of building up this important skill [12].

In spite of the fact that developing the critical thinking skill of understanding the author's message is beneficial for students and is broadly required at language proficiency examinations, school textbooks for the $10^{\text {th }}, 11^{\text {th }}$ and $12^{\text {th }}$ forms include little guidance and scarce practical exercises on the subject. Realizing that the skill of determining the main idea of a text can be developed and mastered with time and practice, teachers feel the necessity to compensate the deficiency of textbook materials elaborating and systematizing their own strategies meant to develop this skill.

Further in this article you will find the description of the strategy elaborated by me which has been applied by me and my colleagues at the lessons of English for four years and has proved to be effective. This strategy provides a model of explicit instruction and practical exercises aimed at gradual development of one of the basic competences of critical reading - determining the main idea of a text, distinguishing it from supporting details and writing the text message.

When teaching students about main idea, it is recommended to grade our instruction. Let students begin with learning the definition of main idea and then apply this definition to identify the main idea in sentences and short texts. Thus, it is necessary for them to realize that the main idea of a paragraph is the author's message about the topic. It is often expressed directly or it can be implied.

Besides, students need to first learn how to identify the concrete and literal before they can determine the inferential [13]. We should slowly work through the following sequence of skills with our readers:

1. First, help students identify key words found within a single sentence asking, "What is the sentence about?"

2. Then, guide students to be able to identify key words in a single paragraph asking, "What is the paragraph about?"

The exercises mentioned in points 1 and 2 are advisable to be practiced beginning with junior forms, as soon as students learn to read whole sentences and short texts in English.

3. Next, suggest short passages that each have a literal topic sentence. Be sure to find examples that have the topic sentence in various positions in the paragraph. This type of practice could be appropriate for eighth- or ninthformers.

4. The following step is a big leap - moving from the literal to the inferential. It is opportune for being exercised with high-school students. Train students in identifying the implied main idea within a single paragraph.

5. Eventually, slowly increase the length of the passage from one paragraph to multiple paragraphs, each time asking students to determine the implied main idea. Note that there is no point in reading longer texts if students can't infer main idea in shorter ones.

What can help students locate the main idea of a paragraph? Once you can find the topic, you are ready to find the main idea. The main idea is the gist of the paragraph. It is the most important thought about the topic. To figure out the main idea, teach your students to identify the following information:

- Who or what the paragraph is about (topic)?

- The most important information about the „who" or „what".

As it has been mentioned above, it is necessary to show students examples that have the topic sentence in various positions in the paragraph. The author can locate the main idea in different places within a paragraph. The main idea is usually a sentence, and it is usually the first sentence. The writer then uses the rest of the paragraph to support the main idea. Students can be given the following example:

Summer is a wonderful time to spend at West Beach. It is a beach with light-colored, soft sand. The coastline goes on for a long way and many people enjoy walking along it. Children like to play in the surf and walk along the rocks that are visible at low tide. This is a fun beach for people of all ages.

In this paragraph:

- the topic is West Beach;

- the main idea (what the writer is saying about the topic) is that summer is a wonderful time at West Beach.

The next most common placement of the main idea is in the last sentence of a paragraph. The author gives supporting information first and then makes the point in the last sentence. Here's a paragraph we can use as an example:

Most teenagers and young adults do not know what they want to do for the rest of their lives. It is 
a big decision. There are a number of things you can do to narrow the choices. For example you can take an interest test, do some research on your own about a career, try volunteer work in the field in which you are interested, or "job-shadow", in which you spend a day with a person who is working in a field that interests you. These are just a few helpful ideas as you begin to choose a career.

In this paragraph:

- the topic is jobs or career choices;

- the main idea is "These are a few ideas to help the reader choose a career".

Finally, an author might put the main idea in the middle of a paragraph. The author will spend a few sentences introducing the topic, present the main idea, then spend the rest of the paragraph supporting it. This can make the main idea more difficult to find. Let's analyze the paragraph below.

The United States seems to be in love with the idea of going out to eat. Because of this, a real variety of restaurants has come about specializing in all kinds of foods. McDonald's is the king of a subgroup of restaurants called fast-food restaurants. Chances are, no matter where you live, there is a McDonald's restaurant near you. There are even McDonald's in the Soviet Union. Now McDonald's is trying something new. It is called McDonald's Express and there is a test site in Peabody, Massachusetts. It is part of a Mobil gas station. This allows you to fill up with gas and fill up on food at the same time. What will they think of next?

In this paragraph:

- the topic is McDonald's;

- the main idea is in the middle of the paragraph, in the third sentence: „McDonald's is the king of fast food" [7].

When such examples have been demonstrated to students, it is reasonable to pass to multiple choice exercises of the following kind:

\section{Locating the Stated Main Idea - \\ Multiple Choice Exercise [11] \\ Directions:}

Read each paragraph. Mentally determine its topic. Then identify its stated main idea sentence by asking yourself, "What is the one most important point the author wants me to understand about the topic?" The sentence that answers that question is the paragraph's stated main idea sentence.

1. Democracy comes from the Greek word demos, which means "the people," and kratia, meaning "to rule." The term democracy refers to a form of government in which the people govern, either directly or through elected representatives. In other words, it is a set of rules for determining who will exercise the authority of government.

The stated main idea sentence is:

A. The term democracy refers to a form of government in which the people govern, either directly or through elected representatives.

B. The meaning of the term democracy.

C. In other words, it is a set of rules for determining who will exercise the authority of government.

2. In Africa, music is usually performed outdoors. There is spontaneous music making as well as performances by social and music groups at ceremonies and feasts. There is no musical notation (written music). African music tradition, like folklore and history, is transmitted orally. Music is a social activity in which almost everyone participates. Clearly, African music has several interesting characteristics.

The stated main idea sentence is:

A. In Africa, music is usually performed outdoors.

B. There is no musical notation (written music).

C. Clearly, African music has several interesting characteristics.

Such exercises can be made up by the teacher based on schoolbook texts or other sources, also they can be found on a number of internet sites, for instance:

McGraw-Hill Global Education Holding https:// www.mheducation.com/

Pinterest.com https://highered.mheducation. com/sites/0073123587/student_view0/chapter8/ locating_the_stated_main_idea_multiple-choice_exercise.html

MAINIDEASrevised815.doc https://www.mdc. edu/kendall/collegeprep/documents2/main $\% 20$ ideasrevised815.pdf

The following tips may also aid students in writing the message of the text where the main idea is stated directly by the author:

Tip 1: Reduce lists and classify. Give a category name. e.g. , an exercise-book”, ,a pencil-case”, ,,a pen” - school supplies; „a cow”, „a goat”, „a horse” - domestic animals.

Tip 2: Cross out repeated information.

Tip 3: Cross out unimportant details.

Tip 4: Select the topic sentence.

Tip 5: Write the topic sentence in your own words (paraphrase) [5].

When students achieve confidence in identifying the literal topic sentence of a paragraph and writing the main idea statement, we should shift from the literal to the inferential. 
The ability to draw inferences from a text is fundamental to critical reading. Often, the main idea of what we read is not stated directly by the author, but it is implied, or hinted at. Prentice Hall „Grammar and Composition", 1990, suggests that one aspect of critical thinking is the ability to examine details in the writing and to make inferences about the main idea. Any conclusions we draw must be based on the details of the information we are given [8].

A valid inference is a logical or reasonable conclusion (or prediction) drawn from the information given. An invalid inference is interpretation or statement that does not follow from the information given. For example:

INFORMATION GIVEN: Pete works hard delivering sixty-two papers on his paper route every day.

VALID INFERENCE: Pete probably earns a fair amount of money per month.

INVALID INFERENCE: Someday Pete will be the editor of the newspaper.

The second statement is a valid inference because one can draw the conclusion that Pete earns money from the information given - that he works hard at a job. The third statement is an invalid inference because the conclusion drawn is not based on the facts given. Just because Pete works hard delivering papers is no indication that he has either the desire or the ability to be the editor of a newspaper someday.

In order to train students in drawing inferences teachers should first of all explain to them that sometimes an author states exactly what he or she means in direct language. More often, however, ideas are not stated directly. In this case they must uncover the meaning. They must act like a detective to observe clues and draw logical conclusion from the material that is presented. This is called making inferences [14].

To help students draw valid inferences from the materials they are analyzing, teachers are recommended to ask them the following type of questions: [8]

1. What details give clues to the main idea of the material?

2. What main ideas do you conclude from these details?

3. Does your conclusion follow reasonably from the inferences you have made?

4. Are there other conclusions you could draw from the same details? What are they?

Passing from the literal to the implied is always a great challenge for students as they are always "looking" for the answer. They need to know the main idea is not usually in the reading, but rather about the reading. Implied ideas can be drawn from facts, reasons, or examples that give hints or suggestions concerning the main idea. These hints will be clues leading students to discover the main idea in the selected text.

A good way to help with this is considering the connection between main idea and a title. A title alerts the reader to what the text will be about. It indicates not only the subject or topic, but also the perspective and attitude. It tells the reader what about the topic will be explained within the reading. Titles are main ideas [13].

Actually, entitling the text, students are determining its main idea. An effective exercise to draw students' attention to this correlation may be removing the title before reading a passage, then reading the text and asking your students, "What could be the title of this text? What was this text mostly about?" Then compare it to the original title to see how close the students came.

Anyway identifying the implied main idea students should define:

$>$ Who or what the paragraph is about (topic)?

$>$ The most important information about the „who" or ,what".

Then they are taught to combine the above elements into a main idea statement with 10 words or less, eliminating nonessential details.

Undoubtedly it is necessary to do a lot of practical exercises in order to develop the skill of main idea inference. Multiple choice exercises are also a good way of training in this regard. They can be made up or found in internet resources including those mentioned above. Here is an example of such exercises.

\section{Determining the Implied Main Idea - Multiple Choice Exercise [6]}

Directions: The topic of the paragraph is given. Remember that the topic must be part of the main idea sentence. Read each paragraph. Then select the answer choice that expresses its implied main idea.

Topic: results of a survey about teens and money

A recent survey revealed some shocking results. One in five teens does not know that if you take out a loan, you must pay interest in addition to repaying the loan. One teen in four has the mistaken notion that financial aid will take care of all their college expenses. And one teen in three thinks that Social Security payments will provide all the money they need when they retire. 
A. A recent survey revealed some shocking results: one in five teens does not know that if you take out a loan, you must pay interest in addition to repaying the loan.

B. Teenagers do not know anything about money matters.

C. A recent survey revealed some shocking results about how little understanding teens have about money matters.

D. One teen in four has the mistaken notion that financial aid will take care of all their college expenses. And one teen in three thinks that Social Security payments will provide all the money they need when they retire.

Having thoroughly practiced determining main idea in a paragraph and being sure our students have developed this skill, it's time to gradually increase the length of the passage from one to multiple paragraphs. Working with texts consisting of several paragraphs it is helpful to first determine the main idea of each paragraph and only then based on these ideas to write the message of the whole text. NSW Centre For Effective Reading [15] offers simple and proper charts completing which aids students in writing the message of the entire passage:

Title or Topic of the Selection

\begin{tabular}{|c|c|c|c|}
\hline Paragraph & $\begin{array}{c}\text { Who or What is the Paragraph } \\
\text { About? }\end{array}$ & $\begin{array}{c}\text { Most important Information } \\
\text { About the „Who" or „What” }\end{array}$ & Key Details \\
\hline 1 & & & \\
\hline 2 & & & \\
\hline 3 & & & \\
\hline 5 & & & \\
\hline
\end{tabular}

*Note: The Complete Main Idea Statement Is Formed By Combining The „Who” Or „What” Column With The „Most Important Information" Column.

Students may also extend the main idea strategy to complete a main idea log or some other note-taking form.

MAIN IDEA LOG

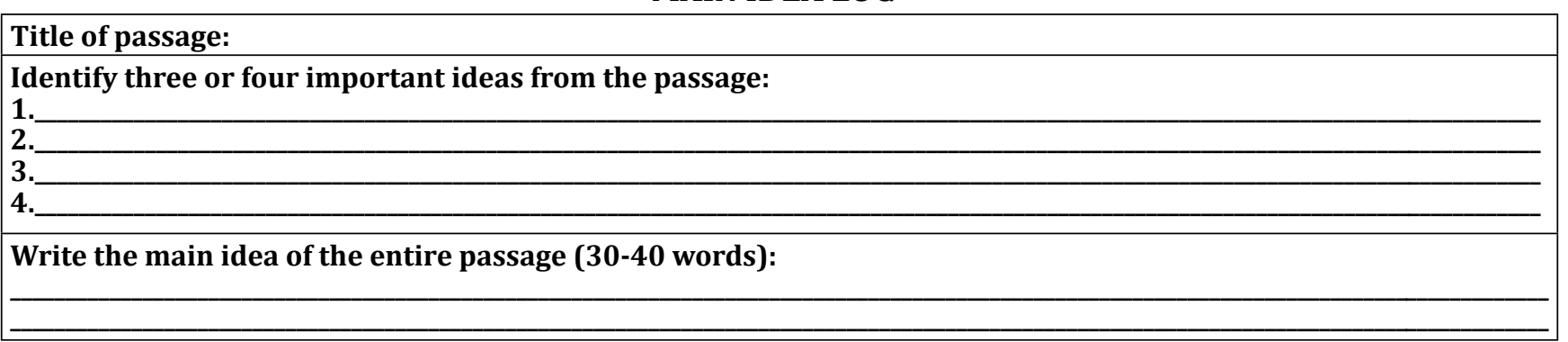

Preparing students for particularly Baccalaureate Examination in English it is imperative to inform them about the requirements they should meet regarding text-message writing and the scheme of text-message examination assessment.

\section{A Good Text-Message: Requirements:}

\section{The Main Idea:}

- The text-message is not a text-summary, but it represents the main idea of the text, or the author's message about the topic. It is often expressed directly or it can be implied.

\section{Paraphrasing:}

- Students must write text messages in their own words. They must not use phrases and sentences from the text - all parts taken from the text are automatically excluded from the text-message and the number of words decreases drastically.

3. Introductory Phrases and Linking Words:

- Students should avoid using Introductory Phrases (e.g. „I think”, „In my opinion”). However, linking words (or logical connectors) (e.g. „although”, „besides”) are welcome.

\section{Word Number:}

- The number of words must be 30-40. 


\section{Text-Message Examination Assessment:}

\begin{tabular}{|c|c|c|c|}
\hline 6 & $\begin{array}{l}\text { Răspuns corect, coerent și complet } \\
\text { Se acordă } 6 \text { puncte pentru formularea mesajului textului în mod } \\
\text { clar și coerent, cu respectarea succesiunii logice a gândului. } \\
\text { Răspuns corect, coerent și incomplet } \\
\text { Se acordă } 4 \text { puncte pentru formularea mesajului textului în } \\
\text { mod clar și coerent, care prezintă unele aspecte ale ideii } \\
\text { principale. } \\
\text { Răspuns parțial corect și incomplet } \\
\text { Se acordă } 2 \text { puncte pentru formularea parțial corectă a } \\
\text { mesajului textului, în care gândurile nu urmează o succesiune } \\
\text { logică. }\end{array}$ & $\begin{array}{l}\mathrm{L} \\
0 \\
2 \\
4 \\
6\end{array}$ & 8 puncte \\
\hline & 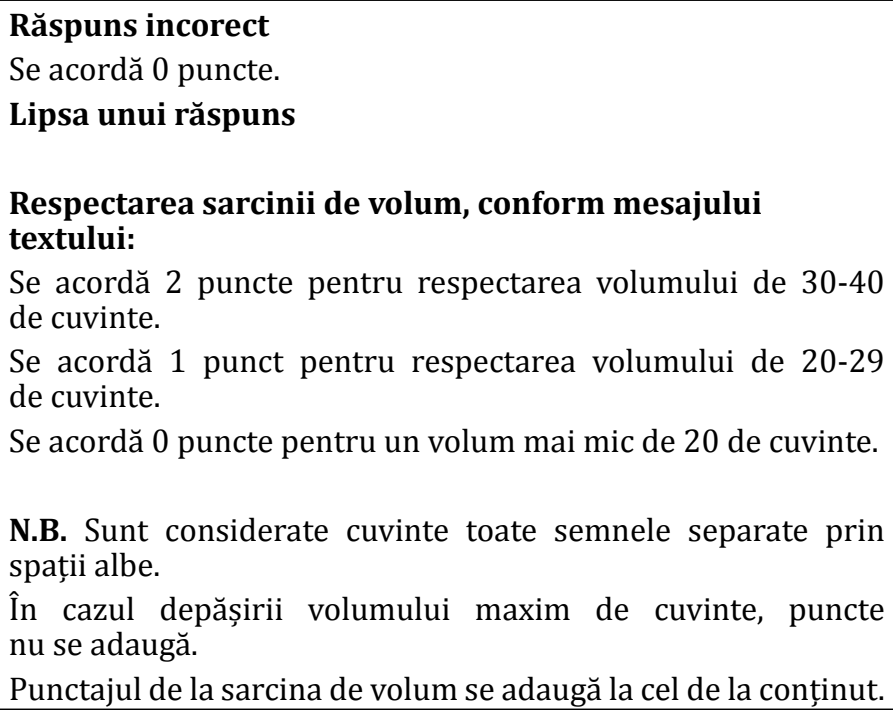 & $\begin{array}{l}\mathrm{L} \\
0 \\
1 \\
2\end{array}$ & \\
\hline
\end{tabular}

Booklets „English Sample Tests for the $12^{\text {th }}$ form pupils to excel at the Baccalaureate exam" which are published every year supply teachers and students with a number of tests for practice. Besides, teachers usually have a rich collection of students' text-messages. It could be a great idea to make up an exercise on their basis asking students to evaluate them according to the exam requirements, identifying the mistakes, commenting on them, suggesting ways of their correction and improvement. This type of activity works very well with my high-school students having proved to be useful and efficient.

In conclusion I'd like to highlight that the skill of identifying a text message should be taught at any proficiency level of students provided that teachers choose a proper instruction and a range of activities corresponding to each level that will lead the stu- dent to the greater purpose of reading. An important thing that teachers should realize is that it is hardly possible to develop this skill in the last semester of the $12^{\text {th }}$ form. It takes years and should be done gradually on a regular basis, scaffolding our instruction and offering students a big number of various exercises for practice.

I hope the described strategy will be useful for my colleagues - teachers of foreign languages - in teaching their students to determine and explain text messages, thus developing their students' critical thinking skills and preparing them for the Baccalaureate examination. As one of the primary goals of education is engaging students in practising thinking, systematic developing their skills of accurate, relevant, reasonable, rigorous thinking will improve the quality of their studies and their life in general. 


\section{REFERENCES}

1. Beyer Barry K. Critical Thinking: What Is It? In: Social Education, v. 49, no. 4 Apr. 1985.

2. Comprehension Handbook. Comprehension - Main Idea. NSW Centre for Effective Reading. [citat 02.02.2021]. Disponibil: https://cer.schools.nsw.gov.au/content/dam/doe/sws/ schools/c/cer/localcontent/comprehension_handbook.pdf

3. Curriculum Național la Limbi străine. Curriculum pentru clasele a 10-a - a 12- $a$. Ministerul Educaţiei al Republicii Moldova. Editura "Ştiinţa”, 2010.

4. Curriculum Naţional la Limba Străină, Clasele X-XII. Ministerul Educaţiei, Culturii şi Cercetării al Republicii Moldova. Chişinău, 2019.

5. Denton C., Bryan D., Wexler J. et al. Effective instruction for middle school students with reading difficulties: The reading teacher's sourcebook. University of Texas Systems / Texas Education Agency, 2007.

6. Elder J. Entryways into College Reading and Learning. Implied Main Idea - Multiple Choice Exercises. [citat 02.02.2021]. Disponibil: https://highered.mheducation.com/sites/0073123587/student_ view0/chapter10/implied_main_idea_exercise_1.html

7. Finding the Main Idea. Columbia College. Disponibil: https://www. ccis.edu/offices/academicresources/writingcenter/studyskills/ textbookreadingstrategies/findingthemainidea.aspx

8. Forlini G. Grammar and Composition. Senior Author. Englewodd Cliffs N.J. „Prentice Hall”, 1990.

9. Ghid de implementare a curriculumului modernizat pentru treapta liceală. Limbi străine. Ministerul Educaţiei al Republicii Moldova. Chişinău: Editura „Cartier”, 2010.

10.Grellet F. Developing Reading Skills. Cambridge University Press, 2002.

11.McGraw-Hill Global Education Holding Locating the Stated Main Idea - Multiple Choice Exercises. [citat 02.02.2021]. Disponibil: https://www.mheducation.com/

12.0rpet B. How to Pass FCE (First Certificate in English), Exam practice in Reading. Paper One, Letts FCE. [citat 02.02.2021]. Disponibil: file:///F:/FCE/FCE_Reading.pdf

13.Smekens Education Solutions, Inc., Helping Students Identify the Main Idea of Any Text. March, 3, 2011. [citat 02.02.2021]. Disponibil: https://www.smekenseducation.com/helping-students-identify-the-m/

14. Wallace C. Critical Reading in Language Education. ELT Journal, Vol. 59/3, July 2005. 